\title{
TECHNIQUES FOR DEVELOPING PATENT DOCUMENTS FOR INVENTION
}

\author{
Erika Stacia Marsailis \\ 155100026 \\ Fakultas Komputer, 448757201 \\ erikastaciamarsailis.student@umitra.ac.id
}

\begin{abstract}
To be able to register a patent for his findings, an expert must be able to compile a patent document. Specific knowledge and expertise is needed to prepare patent documents. The parts of the patent document that must be compiled consist of: Title of the Invention, Field of Engineering Invention, Background of the Invention, Brief Description of the Invention, Complete Description of the Invention, Claims and Abstracts. In the preparation of claims it is recommended to consult a legal expert, so that the meaning of the language of the claim is in accordance with the terminology commonly used in law enforcement. This claim will later become the basis of prosecution in the court when a patented invention is imitated or produced by a person or body that is not permitted by the inventor.

This can happen because there is no integration between the financial and administrative departments so that the presentation of the report is not the same. For this reason, the need for a network-based system proposal to support data processing of cash receipts and disbursements so that the presentation of reports can be done in a structured manner.
\end{abstract}

Keywords: Documents, patents, inventions, claims.

\section{A. INTRODUCTION}

In engineering, new findings or inventions are often produced. These inventions have the potential to be listed as Intellectual Property Rights, one of which is Patent Rights. Patent rights can be divided into two namely "simple patent" and "patent". The most important aspect in registering patent rights is the preparation of patent documents. Can or not an invention is granted patent rights it is 
very much determined by the patent documents prepared, because this document is the first time to be examined and used as a basis by institutions authorized to provide patent protection, in this case in Indonesia, namely the Directorate of Intellectual Property Rights (IPR), The ministry of law and human rights RI. Patent documents are also very important because this document will be TEKNOBUGA Volume 2 No.2 November 201581 which will become the basis for legal protection for law enforcement institutions if the patent that we submit is already registered. Therefore the writing of this article is intended to explain how to technically how to write or compile patent documents, especially patents in the technical field. Chapters Must Be Written in Patent Documents Chapters that must be written in a patent document consist of:

1) Title of Invention In arranging the title of the invention, it should be considered as follows. In general, inventions in the field of engineering that can be patented, can be classified into three, namely:

A. invention of methods or processes of a technology,

B. Formula invention, and

C. product or prototype dimensions. The titles arranged should be explicit, brightly lit indicating the originality of one or a combination of the three types of invention.

2) Field of Invention Engineering In the "Field of invention technique" that needs to be displayed is a brief description of the field of our findings, for example in the fields of automotive, cough medicine, shrimp culture process technology and others. This chapter highlights the renewal and specificity of inventions that are found relative to previous findings.

3) Background of the Invention In this "background" clearly written:

(1) definition of invention found, and

(2) the purpose of the invention which

in general basically states the function of invention in existing technology, for example, completing, renewing, or new design altogether which later will be useful to provide convenience to consumers, save costs, increase goodness, aesthetics, hospitality and so on.

4) A Brief Description of the Invention "Brief Description of the Invention" contains the resume of the invention.

5) The Complete Description of the Invention "Complete Description of the Invention" contains a description of the invention, complete with detailed and short images.

6) This Claim Claim is the legal basis for legal protection of patents. Therefore, in its preparation other than based on science in the field of engineering, it should be consulted with experts in the field of Law.

7) Abstract TEKNOBUGA 201582 Almost the same as writing a research abstract, it's just shorter and highlighted by the renewal of Volume 2 No.2 - November of his research. The Real Example of Compiling Patent Documents at Field of Engineering that has been "Granted (granted patent)" from the Author The author has obtained a patent on "Seal for automotive made from raw materials". Therefore below is an example of a Patent Document which has been successfully issued by the Directorate General of IPR, the Ministry of Law and Human Rights of the Republic of Indonesia as a real illustration of the technique of compiling patent documents. The patent document is presented below. Field of Engineering Invention This invention relates to the process of making shell-based sealing. More specifically related to the process of making lacquer-based sealing which can be used to manufacture seals for components vehicles and piping. Background The invention of seals has been widely used in static machines and dynamic machines and in pipe seals. Previous seals were generally made of rubber, a mixture 


\section{QUIZ Selected Section Class}

of rubber, plastic, plastic alloy, pulp and other materials. The manufacturing process is usually printed by heat, extruded. The disadvantage is that the manufacturing process is relatively difficult, a long processing time. Requires operators who are experts in carrying out the manufacturing process. So it requires a large cost and not economical. In addition, the materials used for making sealing in the previous technology are very slowly decomposed in nature which results in environmental pollution if the waste seals are disposed of carelessly. At the time of installation of seals from the previous technology usually glue is needed to help the installation so that the seals do not shift when tightening the components given sealing.

The next goal is to present a process for making sealing based on lacquers and seals produced. A further objective of the present invention is to provide a process for making shellbased sealing, the process consisting of stages:

Preparing the ingredients, namely: cleaning the lacquer from the impurities - the following impurities such as the remnants of wood twigs, smoothing the cleaned lacquer into flour, and preparing the paper to be coated with lacquer, or preparing the pulp to be mixed with lacquer; Dissolve the flour into the alcohol solvent by stirring until the solution becomes homogeneous; Filter out the homogeneous flour solution using a filter tool, so that the skeleton the lice become filtered and eventually a clean lacquer solution is obtained; Cover the paper with a solution of clean lacquer until blended; Dry the coated lacquer paper at room temperature for 1 to 3 hours; Print the paper coated with clean lacquer in accordance with the desired shape and size of seal. Another way to produce lacquer-based seals is by stages: mixing the pulp into pulp; printing the mixed paper pulp into sheets of paper and printing the sheet of paper is in accordance with the shape and size of the desired seal; You can also print paper pulp that has been mixed with the shell in accordance with the shape and size of the desired seal. Using the above process, a lacquer based seal can be produced which can be used on vehicles, static machinery, pipe joints and others.

\section{B. CONCLUSION}

To be able to register a patent for his findings, an expert must be able to compile a patent document. Specific knowledge and expertise is needed to prepare patent documents. The parts of the patent document that must be compiled consist of: Title Invention, Field of Engineering Invention, Background of the Invention, Brief Description of the Invention, Complete Description of Invention, Claims and Abstracts. In the preparation of claims it is recommended to consult a legal expert, so that the meaning of the language of the claim is in accordance with the terminology commonly used in law enforcement. This claim will later become the basis of prosecution in the court when a patented invention is imitated or produced by a person or body that is not permitted by the inventor. If you do not want to see what you are doing, you'll be able to find out what's going on. If it is not available, then the data will be saved and the data will be retrieved and the data will be retained by the penalty files.

\section{ACKNOWLEDGEMENT University Of Indonesia University Of Mitra Indonesia Telkom University University Of Mellbourne Saitama University}


[1] A. S. Putra And O. M. Febriani, "Knowledge Management Online Application In Pdam Lampung Province," In Prosiding International Conference On Information Technology And Business (Icitb), 2018, Pp. 181-187.

[2] A. S. Putra, O. M. Febriani, And B. Bachry, "Implementasi Genetic Fuzzy System Untuk Mengidentifikasi Hasil Curian Kendaraan Bermotor Di Polda Lampung," J. Sist. Inf. Dan Manaj. Basis Data, Vol. 1, No. 
1, Pp. 21-30, 2018.

[3] O. M. Febriani And A. S. Putra, "Sistem Informasi Monitoring Inventori Barang Pada Balai Riset Standardisasi Industri Bandar Lampung," J. Inform., Vol. 13, No. 1, Pp. 90-98, 2014.

[4] Putra, Arie Setya. "2018 Artikel Struktur Data, Audit Dan Jaringan Komputer." (2018).

[5] Putra, A. S. (2018, July 17). Paperplain Fundamental Create Application With Borland Delphi 7.0 University Of Mitra Indonesia. Retrieved From Osf.Io/Pbrn9.

\section{E. REFERENCE(Based APA )}

Putra, A. S., Aryanti, D. R., \& Hartati, I. (2018, November). Metode SAW (Simple Additive Weighting) sebagai Sistem Pendukung Keputusan Guru Berprestasi (Studi Kasus: SMK Global Surya). In Prosiding Seminar Nasional Darmajaya (Vol. 1, No. 1, pp. 85-97).

Sari, D. P., Febriani, O. M., \& Putra, A. S. (2018, November). Perancangan Sistem Informasi SDM Berprestasi pada SD Global Surya. In Prosiding Seminar Nasional Darmajaya (Vol. 1, No. 1, pp. 289-294).

Putra, A. S. (2018). Paperplain: Execution Fundamental Create
Application With Borland Delphi 7.0 University Of Mitra Indonesia.

Putra, A. S., Sukri, H., \& Zuhri, K. Sistem Monitoring Realtime Jaringan Irigasi Desa (JIDES) Dengan Konsep Jaringan Sensor Nirkabel. IJEIS (Indonesian Journal of Electronics and Instrumentation Systems), 8(2), 221232.

Darmawan, A., Yuliawati, D., Marcella, O., \& Firmandala, R. (2016). Sistem Absensi dan Pelaporan Berbasis Fingerprint dan SMS Gateway. EXPLORE, 7(1).

Febriani, O. M., Wahyuni, T., \& Yusuf, S. (2017). DESIGN OF WEBSITE-BASED INFORMATION SYSTEM FOR EDOCUMENT ADMINISTRASI IN THE COMMUNITY SERVICE UNIT (A Case Study at Rajabasa District). INTERNATIONAL JOURNAL OF COMPUTERS \& TECHNOLOGY, 16(7), 7010-7020.

Febriani, O. M., \& Wahyuni, T. (2017, October). PERANCANGAN SISTEM E-DOCUMENT ADMINISTRASI LOGBOOK PENELITIAN PADA UNIT LAYANAN DI BANDAR LAMPUNG. In Prosiding Seminar Nasional Darmajaya (Vol. 1, No. 1, pp. 187-194).

Febriani, O. M., \& Permadi, A. B. (2017). Implementasi Sistem Aplikasi Data Bimbingan dan Pelanggaran Siswa pada Sekolah Menengah Atas di Lampung Tengah dengan Metode Analisis dan Desain Sistem Terdistribusi (SSAD). EXPERT, 7(1). 
Febriani, O. M., \& Ambarwati, L. (2015). PERANCANGAN APLIKASI PENGOLAHAN DATA PENJUALAN UKM KELANTING KHAS TELO DESA SIDOHARJO KECAMATAN JATI AGUNG KABUPATEN LAMPUNG SELATAN. Jurnal Teknologi Informasi dan Bisnis Pengabdian Masyarakat Darmajaya, 1(1), 77-95.

Febriani, O. M. (2015). Rancang Bangun Aplikasi Ecommercemenggunakan Freewebstore pada UKM Kelanting di Desa Sidoharjo Lampung Selatan. Prosiding Sembistek 2014, 1(02), 446-458. 